\title{
DETERMINANT OF THE HOUSEHOLD'S EXPENDITURE OF THE RECIPIENTS OF SOCIAL ASSISTANCE PROGRAM IN BANDAR LAMPUNG CITY
}

\author{
Ica Rizki Aneftasari ${ }^{1 *}$, Bustanul Arifin ${ }^{2}$, Muhammad Irfan Affandi ${ }^{3}$ \\ Department of Agribusiness, Lampung University, Indonesia \\ *corresponding author: icaraneftasari@gmail.com
}

\begin{abstract}
Poverty is a major concern and a serious problem faced by the entire world population, including Indonesia. One of the programs implemented by the Indonesian government is the Social Assistance Program (PKH). This program is in the form of providing social assistance and protection to the recipients of the social assistance programs. This study aims to analyze the factors that influence household expenditure on the recipients of the social assistance program. This research was conducted in Rajabasa and Bumiwaras Villages, Rajabasa District, Bandar Lampung City. With respondents as many as 76 the recipients of social assistance program taken using the proportional random sampling method from the total population of the recipients of social assistance program Rajabasa and Bumiwaras Districts. To analyze the determinant is by using the Ordinary Least Square method. The results showed that the variables of income, the recipients of social assistance program education and the number of family members influenced household's expenditure in Bandar Lampung City.
\end{abstract}

Keywords: Determinant, Expenditure, Household, Social Assistance Program, The Recipients

http://dx.doi.org/10.21776/ub.agrise.2022.022.1.1

Received 28 July 2021

Accepted 25 January 2022

Available online 31 January 2022

\section{INTRODUCTION}

Poverty is a major concern and a serious problem faced by the entire world population, including in the State of Indonesia. According to the World Bank (2018), every year Indonesia experiences a change, namely the decline in the number of Indonesians living below the poverty line. People who are below the poverty line need intervention from the government to get out of the poverty trap. One of the programs implemented by the Indonesian government, namely in poverty alleviation, is the Social Assistance Program (PKH). PKH is conditional cash assistance for poor families given to $\mathrm{PKH}$ recipients or recipients families of the social assistance programs. The requirement for $\mathrm{PKH}$ assistance is that they must actively participate in education and health.

Poverty alleviation must certainly be the main focus for the government, considering that in Indonesia there are still many poor people. Based on data obtained by the Central Statistics Agency (BPS) (2021) it was found that the poverty rate in Indonesia as of March 2021 reached 10.19 per cent. This figure is still smaller than the poverty rate in

Lampung Province in 2020 of 12.34 per cent. Figure 1 is a comparison of the poverty level of Bandar Lampung City, Lampung Province, and Indonesia in 2014-2020. 


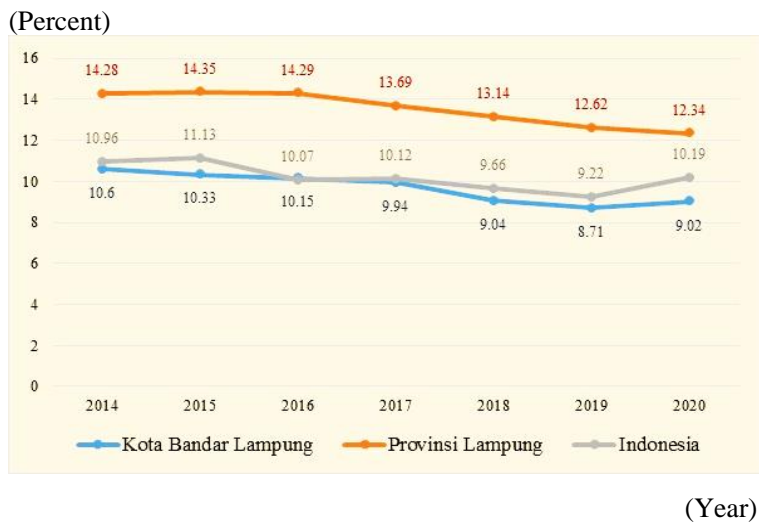

Figure 1. Poverty data for the City of Bandar Lampung, Lampung Province, and Indonesia for 2014-2020

Another cause of poverty is the lack of human resources. If the poor do not have skills, they will not have income which causes less purchasing power so they are trapped in the cycle of poverty. The success of a region depends on the Human Development Index (HDI). HDI is a simple measuring tool to determine the success rate of human resource development. According to BPS (2021), the HDI of Bandar Lampung City which has been achieved in 2020 is 77.44 points. This shows an increase of 0.11 points from 2019 which reached 77.33 points. This condition indicates that the welfare level of the population of Bandar Lampung City is increasing. This condition is unfortunately not matched by a decrease in the number of social problems. BPS noted that in 2017 the number of social problems in Bandar Lampung City was relatively high. In some cases of social problems, the highest number in Bandar Lampung City is the number of the poor as many as 100.5 thousand people.

Poor households can be seen from their income and expenditure patterns. The pattern of household expenditure is divided into food and non-food expenditures. According to Triana (2011), households that have food expenditures that are greater than non-food indicate that the household is poor. Therefore, this study was conducted to determine household expenditures and what determinants affect the recipients of social assistance program spending in Bandar Lampung City.

\section{RESEARCH METHODS}

The research method used in this research is the survey method. This research was conducted in Rajabasa Subdistrict and Bumiwaras Subdistrict, Bandar Lampung City. The research location was carried out purposively. The research location was chosen based on the consideration that Rajabasa and Bumiwaras sub-districts are one of the poorest areas in Bandar Lampung City.

The sample in this study was the recipients of social assistance programs in this case the housewives. According to Sugiarto (2008) the number of samples is determined by the following formula:

$\mathrm{n}=\frac{\mathrm{NZ}^{2} \mathrm{~S}^{2}}{\mathrm{Nd}^{2}+\mathrm{Z}^{2} \mathrm{~S}^{2}}$

$$
\begin{aligned}
& \text { Explanation: } \\
& \mathrm{n}=\text { Number of samples } \\
& N=\text { Total population } \\
& S^{2}=\text { Sample variation }(5 \%=0,05) \\
& Z=\text { Level of confidence }(95 \%=1,96) \\
& d=\text { Degree of deviation }(5 \%=0,05)
\end{aligned}
$$

The household population in this study was 4,253 recipients of social assistance program households so a total sample of 76 recipients of social assistance programs was obtained. The number of samples per village was taken by proportional random sampling method. Meanwhile, according to Mustafa (2009), proportional sampling can be done with the following formula:

$\mathrm{ni}=\frac{\mathrm{Ni}}{\mathrm{N}} \times \mathrm{n}$

Explanation:

$n_{a b}=$ sub-district sample

$N_{a b}=$ sub-district population

$N=$ total population of $\mathrm{a}$ and $\mathrm{b}$ sub-districts

$n$ = number of samples of $\mathrm{a}$ and $\mathrm{b}$ sub-districts

Based on the formula above, the sample size for each sub-district is 24 recipients of the social assistance program Sub-district and Bumiwaras District 52 recipients of the social assistance program. The sampling method was carried out using a simple random sampling method.

The data used in this study consisted of primary data and secondary data. The main data is household expenditure data collected through interviews and observations. Direct observation is given in a research setting. To answer the first research problem, a qualitative approach was used from household expenditure observations. Interviews were conducted to complete the questions in the questionnaire. The results of the interviews are presented in tabulated data and analyzed using household expenditures by referring to the details of the calculation of household expenditures based on Sajogyo's (1997) criteria divided into food and non-food expenditures, with the following formula: 
$\mathrm{TPI}=\mathrm{Pf}+\mathrm{Pnf}$

Explanation:

TPI $=$ Total household expenditure on the recipients of social assistance (Rupiah) yearly

Pf = Food expenditure (Rupiah) yearly

Pnf $=$ Non-food expenditure (Rupiah) yearly

Food expenditure and household non-food expenditure of recipients of social assistance programs can be formulated as follows:

$\mathrm{Ct}=\mathrm{Cpi}+\mathrm{Cnpi}$

Explanation:

$\mathrm{Cp}=$ total of the recipients of social assistance household expenditure (Rupiah) yearly

$\mathrm{i}=1,2,3$,

$\mathrm{n}=$ other expenditure

$\mathrm{Cp}=$ total food expenditure (Rupiah) yearly, formulated as follows:

$\mathrm{Cp}=\mathrm{Cpp}+\mathrm{Cuu}+\mathrm{Cph}+\mathrm{Cml}+\mathrm{Cbb}+\mathrm{Ckk}+\mathrm{Cgl}$

$+\mathrm{Csb}+\ldots+\mathrm{Cll}$

$\mathrm{Cpp}=$ rice expenditure $(R p)$ yearly

$\mathrm{Cuu}=$ tubers expenditure $(R p)$ yearly

$\mathrm{Cph}=$ animal food expenditure $(R p)$ yearly

$\mathrm{Cml}=$ oil and fat expenditure $(R p)$ yearly

$\mathrm{Cbb}=$ grains expenditure $(R p)$ yearly

$\mathrm{Ckk}=$ beans expenditure $(R p)$ yearly

$\mathrm{Cg}=$ sugar expenditure $(R p)$ yearly

$\mathrm{Csb}=$ vegetable and fruit expenditure $(R p)$ yearly

$\mathrm{Cll}=$ other expenditure (seasoning, cigarette) $(R p)$ yearly

Cnp $=$ total non-food expenditure $(R p)$ yearly, formulated as follows:

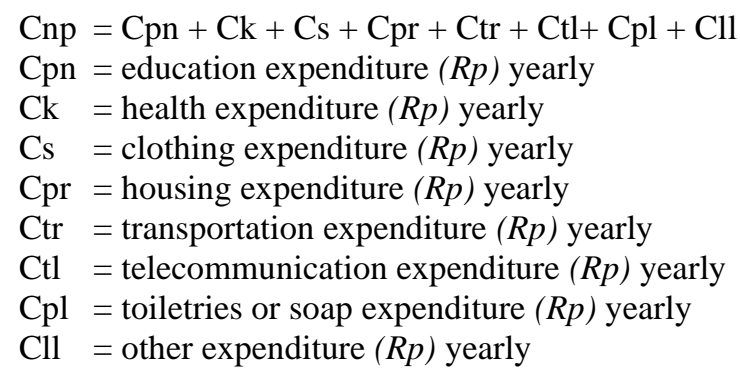

The proportion of food expenditure to the total expenditure of the recipients of social assistance program households can be calculated using the formula below.

$\mathrm{PrPF}=\frac{\mathrm{PP}}{\mathrm{TPl}} \times 100 \%$

Explanation:

$\mathrm{PrPF}=$ Propotion of food expenditure $(\%)$
$\mathrm{PP}=$ Food expenditure $(\mathrm{Rp})$ yearly

$\mathrm{TPl}=$ Total expenditure $(\mathrm{Rp})$ yearly

The proportion of non-food expenditure to the total expenditure of the recipients of social assistance program households can be calculated using the formula below.

$\mathrm{PrPF}=\frac{\mathrm{PNP}}{\mathrm{TPl}} \times 100 \%$

Explanation:

$\mathrm{PrPF}=$ Propotion of non-food expenditure $(\%)$

$\mathrm{PNP}=$ Non-Food expenditure $(\mathrm{Rp})$ yearly

$\mathrm{TPl}=$ Total expenditure $(\mathrm{Rp})$ yearly

To determine the determinants of household expenditure for the recipients of social assistance programs in Bandar Lampung City, several factors that can affect expenditure were taken, namely income, husband's age, wife's age, husband's education, wife's education, and some family members. This analysis consists of one dependent variable and seven independent variables. The variables to be studied are more than two variables, then the analytical tool used is the multiple linear regression method or Ordinary Least Square (OLS). With the following formula:

$Y=\beta_{0}+\beta_{1} X_{1}+\beta_{2} X_{2}+\beta_{3} X_{3}+\beta_{4} X_{4}+\beta_{5} X_{5}+e$

Where:

$\mathrm{Y}=$ total household expenditure ( $\mathrm{Rp}$ yearly)

$\beta_{0}=$ intercept

$\beta_{1, \ldots}, \beta_{7}=$ regression coefficient

$\mathrm{X}_{1}=$ income (million Rp/year)

$\mathrm{X}_{2}=$ age (year)

$\mathrm{X}_{3}=$ husband's education (success year)

$\mathrm{X}_{4}=$ wife's education (success year)

$\mathrm{X}_{5}=$ number of family members (person)

e $=$ error standard

Classical assumption test includes multicollinearity test and heteroscedasticity test. To determine the effect of independent variables on the dependent variable, the t-test and F-test were carried out. The t-test was conducted to determine the effect of each independent variable on the dependent variable. The $\mathrm{F}$ test was conducted to determine the effect of all independent variables on the dependent variable.

\section{RESULTS AND DISCUSSION}

General Condition of Bandar Lampung City and Characteristics of Sample Households

Bandar Lampung City is the capital city of Lampung Province. This city is a centre of trade, industry, and tourism because of its strategic 
location between the islands of Sumatra and Java. Bandar Lampung City has an area of $197.22 \mathrm{~km} 2$ consisting of 20 sub-districts and 126 urban villages. According to BPS (2019), the population in Bandar Lampung City in 2019 reached $1,033,803$ people with 520,078 men and 513,725 women.

Most of the recipients of social assistance programs are aged 22-45 years ( 85.53 per cent). the majority of the recipients of social assistance program educated up to junior high and high school level as many as 53 people ( 69.73 per cent), while the husbands of the recipients of social assistance program mostly have elementary and junior high school education levels as many as 49 people (64.47 per cent). The number of recipients of social assistance program family members in Bandar Lampung City ranges from 3 to 10 people ( 81.57 per cent). Most of the respondents have income $\leq$ Rp. 2,415,000.00 per month (53.95 percent). Sources of income for the recipients of the social assistance program in Bandar Lampung City are from husband's income, wife's income, side work, social assistance program fund assistance and BPNT assistance.

\section{The Household's Expenditure Pattern of the Recipients of Social Assistance Program}

In general, the need for goods and services in households consists of two groups, namely food and non-food needs. The expenditures studied in this study were food and non-food expenditures for the recipients of social assistance program households in Bandar Lampung City. Details of food and non-food expenditures can be seen in Table 1 .

In the results of the study, food expenditure (50.64 per cent) was greater than non-food expenditure (49.36 per cent). This is in line with the research conducted by Bahrun, Syaparuddin and Hardiani (2013) which states that the expenditure

Table 1. The Details of food and non-food expenditures

\begin{tabular}{lr}
\hline \multicolumn{1}{c}{ Expenditure type } & \multicolumn{1}{c}{$\begin{array}{c}\text { Average } \\
\text { expenditure }\end{array}$} \\
\cline { 2 - 2 } & \multicolumn{1}{c}{ (Rp/year) } \\
\hline Food Expenditure & \\
\hline Rice & $3.469 .342,00$ \\
Tuber & $470.565,80$ \\
Animal Product & $2.034 .050,00$ \\
Oil and Fat & $464.210,50$ \\
Grains & $41.210,53$ \\
Beans & $848.223,68$ \\
Sugar & $887.526,31$
\end{tabular}

\begin{tabular}{lr} 
Vegetables and fruits & $2.038 .252,63$ \\
Seasoning & $219.947,37$ \\
Cigarette & $3.258 .157,89$ \\
\hline Total food expenditure & $\mathbf{1 3 . 7 3 1 . 4 8 6 , 8 4}$ \\
\hline Non-food Expenditure & \\
\hline Transportation/fuel & $2.279 .178,95$ \\
Education Cost & $4.449 .269,74$ \\
Cleaning expenditure & $895.407,90$ \\
Cosmetics expenditure & $273.059,21$ \\
Electronic & $368.881,58$ \\
Clothes & $1.121 .828,90$ \\
Telecommunication & $1.320 .473,70$ \\
Social & $2.154 .473,00$ \\
Taxes & $79.866,45$ \\
Other & $443.618,42$ \\
\hline Total non-food expenditure & $\mathbf{1 3 . 3 8 6 . 0 5 8 , 5 5}$ \\
\hline
\end{tabular}

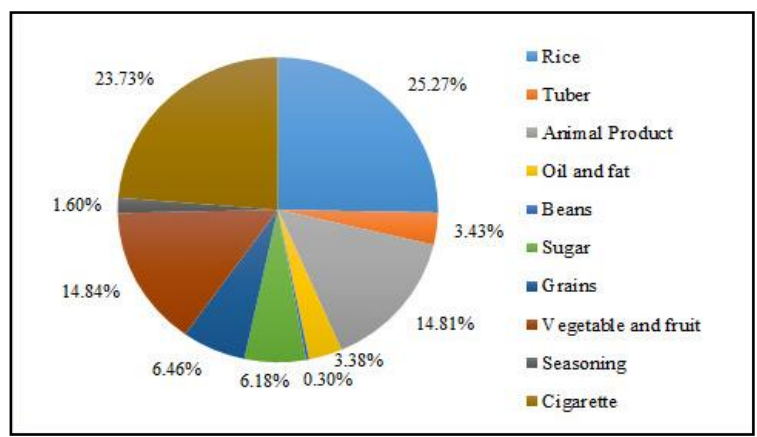

Figure 2. Percentage of food expenditure for KPM $\mathrm{PKH}$ in Bandar Lampung City

a pattern of very poor households in Sarolangun Regency is on average higher food consumption (72.96 per cent) than non-food consumption (12.07 per cent). The burden of household food expenditure is reduced due to financial assistance from the government. The results of this study are in line with Prianti, Arifin and Nugraha (2016), there is a 4.69 per cent reduction in the expenditure burden on household grains after Raskin. In detail, the recipients of the social assistance program food expenditure can be seen in Figure 2.

In food expenditure, grain commodities as a staple food have the highest percentage of 25.27 per cent. The expenditure on grains is the highest because rice is the staple food of the people of Bandar Lampung City. According to research by Hasibuan and Lestari (2016), rice expenditure (31.4 per cent) is the highest of other food expenditures.

In this study, it was found that household expenditure on cigarettes (23.73 per cent) was almost one and a half times more than animal food expenditure (14.81 per cent). This is in line with the results of Ahsan (2009) which states that the expenditure on cigarettes for the poorest smoking households is 17 times more than the expenditure on meat, 5 times more than the expenditure on milk and eggs and 2 times more than the expenditure on fish. Most of the husbands of the recipients of social assistance programs work as labourers and active smokers. They smoke while working to be 
more enthusiastic at work. This is supported by the opinion of Riskesdas Lampung Province (2018), farmers/labourers are the active smoker group which has the largest proportion compared to other occupational groups, namely 69.92 per cent. The high proportion of cigarette spending must be watched out for, considering that the price of cigarettes is not cheap, smoking is also not recommended from a health perspective.

The following is the average percentage of non-food expenditure of the recipients of social assistance program households in Bandar Lampung City, which can be seen in Figure 3.

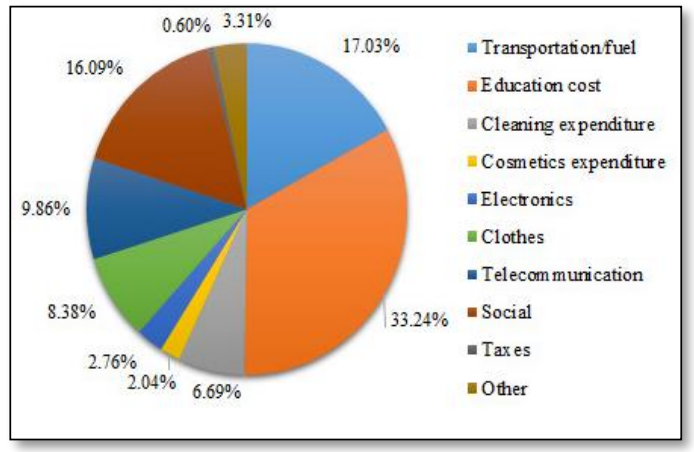

Figure 3. Percentage of non-food expenditure of KPM PKH in Bandar Lampung City

The highest non-food expenditure was the cost of education at 33.24 per cent. This is in line with the research of Fatimah and Syamsiah (2018) which states that education needs are the highest expenditure when compared to other expenditures. According to Rahardja, Pratama and Manurung (2005) education is an important investment. A good education can make a person the opportunity to get a better job so that it can improve household welfare.

In this study, it was found that non-food expenditure for social costs was 16.09 per cent and expenditure for transportation/fuel was 17.03 per cent. This is in line with the research results of Hasibuan and Lestari (2016) which states that the highest non-food expenditures are housing and fuel expenditures (33.1 per cent) of other non-food expenditures. In the study area, transportation costs are higher for households because most of the recipients of social assistance programs work as drivers, offline motorcycle taxi drivers and online motorcycle taxi drivers. Non-food expenditure for communication is 9.86 per cent. In the research area, most of the recipients of social assistance programs already understand technology so that non-food expenditure for communication is allocated for quota and credit needs.
Determinant of the Household's Expenditure pattern of the Recipients of Social Assistance Program in Bandar Lampung City

The effect of the independent variable on the dependent variable (the recipients of social assistance program household expenditure in Bandar Lampung City), was analyzed using the SPSS (Statistical Package for Social Science) version 26.00 program. Before the regression analysis and the model form, the classical assumption test was carried out. The classical assumption test conducted in this study is the multicollinearity test and the heteroscedasticity test. To see the symptoms of heteroscedasticity, Eviews version 10 will be used. The multicollinearity test is carried out to determine whether there is a correlation between the independent variables, while the heteroscedastic test is carried out to determine whether there is an error or the residual from the observed model does not have a constant variance from one observation to another. The test results can be seen in Table 2 .

According to Ghozali (2006), in the multicollinearity test, if the independent variables are highly correlated (above 0.9 ) and the R2 value as a measure of goodness of fit generated by a high empirical model estimate, the VIF value (variance inflation factor) $>10$ then indicates the presence of multicollinearity. If $\mathrm{VIF}<10$ and tolerance value > 0.1 , then there is no multicollinearity. In Table 2, the VIF value generated from each variable is less than 10 and the tolerance value is $>0.1$ so that the variables are not highly correlated. Thus, it can be concluded that the regression model does not experience symptoms of multicollinearity. The results of the heteroscedastic symptom test with the white test can be seen in Table 2 . The output results on the white heteroscedastic test show the value of Obs * R-squared is 11.056 , while the probability value (chi-square) is 0.0503 (greater than $=0,05$ ), thus the null hypothesis is accepted. This hypothesis means that it does not contain symptoms of heteroscedasticity.

Based on Table 2, the linear regression equation that can be used in this study is as follows.

$$
\begin{aligned}
Y= & -2,595+0,766 X_{1}+0,085 X_{2}+0,231 X_{3} \\
& -0,381 X_{4}+0,963 X_{5}
\end{aligned}
$$

The results obtained for the recipients of the social assistance program household expenditure function model in Bandar Lampung City are presented in Table 2 .

Table 2. The results of the estimation of the recipients of social assistance program household expenditures in Bandar Lampung City 


\begin{tabular}{|c|c|c|c|c|}
\hline Variable & Coef & $\mathrm{t}$-Stat & Sig & VIF \\
\hline Constanta & 2,595 & $-0,615$ & 0,540 & \\
\hline $\mathrm{X}_{1}$ & 0,766 & 12,045 & 0,000 & 1,375 \\
\hline $\mathrm{X}_{2} * * *$ & 0,085 & 1,188 & 0,239 & 1,132 \\
\hline $\mathrm{X}_{3}$ & 0,231 & 1,255 & 0,213 & 1,340 \\
\hline $\mathrm{X}_{4} *$ & 0,381 & $-1,760$ & 0,083 & 1,375 \\
\hline $\mathrm{X}_{5} * *$ & 0,963 & 2,248 & 0,028 & 1,316 \\
\hline $\begin{array}{l}\text { F-count } \\
R \text {-squared }\end{array}$ & $\begin{array}{r}49,787 \\
0,781\end{array}$ & & 0,000 & \\
\hline \multicolumn{2}{|c|}{ Orbs $R$-Squared 11,056} & \multicolumn{2}{|c|}{ Prob Chi Square } & 0,053 \\
\hline Explanation: & & gnifica & level o & $\begin{array}{l}9 \% \\
5 \% \\
90 \%\end{array}$ \\
\hline
\end{tabular}

Based on the statistical test of the results of the regression of the factors that influence household expenditure on the recipients of social assistance program, it is obtained R Square or R2 of 0.781 which means that 78.10 per cent of the variables of household expenditure on the recipients of social assistance program in Bandar Lampung City can be explained by variations of the six independent variables while the rest 21.90 per cent are influenced by other variables not included in the model. Based on the explanation above, further research should include other variables that have not been included in the mode, such as ethnic and environmental variables.

Based on the estimation results, three variables have a significant effect on household spending on the recipients of social assistance in Bandar Lampung City, namely income (X1) with a confidence level of 99 per cent, the number of family members (X5) has a significant effect with a confidence level of 95 per cent and the recipients of social assistance education (X4) with a confidence level of 10 per cent, while the age variables of the recipients of social assistance (X2) and the recipients of social assistance husband's education (X3) have no significant effect on household expenditures for the recipients of social assistance in Bandar Lampung City.

The calculated $F$ value is 49.787 with a probability value of 0.000 . This explains that together the income variables (X1), age of the recipients of social assistance (X2), husband's education (X3), education of the recipients of social assistance (X4) and many family members (X5) have a significant effect on the recipients of social assistance household expenditures in the city. Bandar Lampung with a confidence level of 99 per cent.

The t-test was conducted to determine the effect of each independent variable (X) on the dependent variable (Y). The results of the t-test can be seen in Table 2, the effect of each independent variable $(\mathrm{X})$ on the dependent variable $(\mathrm{Y})$ is seen based on the significant value of the regression results. If the significant value of each independent variable is $<0.1$, then the independent variable has a significant effect on the dependent variable. The test results can be described:

\section{a) Income ( $\left.X_{1}\right)$}

Based on the results of the analysis obtained, household income has a significant effect on household expenditure on the recipients of social assistance in Bandar Lampung City with a confidence level of 99 per cent. This means that if other variables remain constant, every increase in income of one million rupiahs will increase household expenditure by 0.766 million rupiahs per year. If there is an increase in household income, it will be followed by an increase in household expenditure because housewives can add or change the family's daily menu, which usually they consume tempeh, they can buy more expensive food such as fish, chicken, and others. In addition, with the increase in income, they also get several options to buy the goods they need. Selian and Jannah (2018) state that the income variable has a significant and positive influence on household consumption patterns of poor families in Disadvantaged Villages, Central Aceh Regency.

\section{b) The recipients of social assistance age $\left(X_{2}\right)$}

The age of the recipients of social assistance has no significant effect on the household expenditure of the recipients of social assistance in Bandar Lampung City. This is in line with research conducted by Hildayanti, Jenahar and Oemar (2017) that age does not affect household expenditures of rubber farmers in Banyuasin Regency, South Sumatra.

\section{c) husband's education $\left(\mathrm{X}_{3}\right)$}

Based on the results of the analysis obtained, the husband's education has no significant effect on the recipients of social assistance household expenditures in Bandar Lampung City. In practice, most husbands of the recipients of social assistance leave the financial arrangements for family needs to their wives.

\section{d) The recipients of social assistance's Education $\left(\mathbf{X}_{4}\right)$}

The recipients of social assistance's education have a significant negative effect on the recipients of social assistance's household spending in Bandar City with a confidence level of 90 per cent. This shows that if other variables remain constant, an increase of one year of education in the recipients of social assistance will reduce household spending on the recipients of social assistance by 0.381 million rupiahs per year. A mother has a big role in the family, from shopping for food, arranging the 
family meal menu, distributing food, managing finances and expenditures and others. The education level of the recipients of social assistance as a housekeeper, besides being the main capital in supporting the family economy, also plays a role in the preparation of family diets and regulating family finances. Based on research conducted by Hildayanti, Jenahar and Oemar (2017) formal education has a significant and negative effect on household spending. This is in line with research conducted by Divine, Adri and Triani (2018) which states that higher education has a negative and significant effect on household consumption expenditures in Indonesia.

\section{e) Number of family members $\left(X_{5}\right)$}

The number of family members has a significant effect on the recipients of social assistance's household expenditures in Bandar Lampung City with a confidence level of 95 per cent. This means that if other variables remain constant, an increase in one family member will cause household spending to increase by 0.963 million rupiahs per year. This is in line with the research of Hildayanti, Jenahar and Oemar (2017) that the number of family members affects household spending. The more family members, the more they need for household expenditures, especially for each need in the family because the needs will be more varied considering that everyone has different tastes and needs.

\section{CONCLUSION}

From the explanation above, it can be concluded that the average food expenditure of the recipients of social assistance's households per year is Rp. $13,731,486.84$ with a greater contribution $(50.64 \%)$ than the non-food expenditure of Rp. $13,386,058.55$ per year (49.36). \%). The determinants of household expenditure on the recipients of social assistance in Bandar Lampung City are the income variable, the wife's education variable and the variable number of family members.

\section{REFERENCES}

Ahsan A. 2009. Peningkatan Cukai Tembakau dan Dampak Perekonomian. TCSC-IAKMI. Jakarta.

Badan Pusat Statistik. 2019. Statistik Daerah Provinsi Lampung Tahun 2019. Badan Pusat Statistik Provinsi Lampung. Bandar Lampung.

Badan Pusat Statistik. 2021. Statistik Daerah Provinsi Lampung Tahun 2021. Badan Pusat Statistik Provinsi Lampung. Bandar Lampung.
Bahrun, Syaparuddin dan Hardiani. 2013. Analisis Pendapatan dan Pola PengeluaranRumah Tangga Miskin di Kabupaten Sarolangun. Jurnal Jurnal Perspektif Pembiayaan dan Pembangunan Daerah. Vol 2(1): 1-8.

Fatimah N dan Syamsiyah N. 2018. Proporsi Pengeluaran Rumah Tangga Petani Padi di Desa Patimban Kecamatan Pusakanagara Kabupaten Subang, Jawa Barat. Jurnal pemikiran Masyarakat Ilmiah Berwawasan Agribisnis. Vol. 4(2):184-196.

Ghozali. 2006. Aplikasi Analisis Multivariate dengan Program Program SPSS. Badan Penerbit Undit. Semarang.

Hasibuan LS dan Lestari R. 2016. Analisis Pola pengeluaran Rumah Tangga Miskin di Kabupaten Simalungun. Jurnal Ekonomikawan. Vol. 16(1):38-55.

Hildayanti SK, Jenahar TJ dan Oemar H. 2017. Faktor-Faktor yang Mempengaruhi Pengeluaran Rumah Tangga Petani Karet di Kabupaten Banyuasin Sumatera Selatan. Jurnal Ecoment Global. Vol. 2 (2):57-62.

Illahi N, Adry MR dan Triani M. 2018. Analisis Determinan Pengeluaran Konsumsi Rumah Tangga di Indonesia. EcoGen. Vol. 1 (3):549-556.

Jhingan ML. 2016. Ekonomi Pembangunan dan perencanaan. Jakarta. Rajawali.

Mustafa Z. 2009. Mengukur Variabel hingga Instrrumentasi. Graha Ilmu. Yogyakarya.

Prianti E, Arifin B dan Nugraha A. 2017. Peran Kebijakan Raskin terhadap Pola Pengeluaran Rumah Tangga Penerima Raskin di Kota Bandar Lampung. JIIA (Jurnal Ilmu-Ilmu Agribisnis). Vol. 5(4):352-359.

Rahardja, Pratama, Manurung M. 2005. Teori Ekonomi Makro. Fakultas Ekonomi Universitas Indonesia. Jakarta.

Riskesdas. 2018. Laporan Provinsi Lampung Riskesdas Tahun 2018. Lembaga Penerbit Badan Penelitian dan Pengembangan Kesehatan. Jakarta.

Sajogyo. 1977. Garis Kemiskinan dan Kebutuhan Minimum Pangan. Bogor: LPSP.

Selian DA dan Jannah M. 2018. Faktor-Faktor yang Mempengaruhi Pola Konsumsi Rumah Tangga Keluarga Miskin di Desa Tertinggal Kabupaten Aceh Tengah. Jurnal Ekonomi dan Bisnis Islam. Vol. 3(1):1-20.

Sugiarto. 2008. Metode Statistika. PT Gramedia Pustaka Utama. Jakarta.

Triana RAL. 2011. Pengaruh Kebijakan Subsidi Beras Miskin dan Bantuan Langsung Tunai terhadap Pengeluaran Telekomunikasi dan Rokok Rumah Tangga Miskin di Pulau Jawa. Tesis. Sekolah Pascasarjana, Institut Pertanian Bogor. Bogor 
World Bank. 2018. Poverty Headcount Ratio at

National Poverty Lines.

Http://data.worldbank.org/. World Bank.

World Development Indicators 